\title{
ULTIMAS TENDENCIAS EN EL MANEJO NUTRICIONAL DEL NIÑO CON ENFERMEDAD RENAL CRONICA:UN DESAFIO PARA TODOS
}

\author{
AdELA HERRERA, N.D.
}

\section{RESUMEN}

La enfermedad renal crónica (ERC) es un proceso fisiopatológico, cuya consecuencia es la pérdida del número y funcionamiento de nefronas, desembocando a menudo en insuficiencia renal terminal, la que se considera un problema de salud pública en el mundo. La ERC se caracteriza también por la falla de la función en grados variables de intensidad con innumerables repercusiones derivadas de la acumulación de los productos finales del metabolismo con alteración del equilibrio hidroelectrolítico y acido base, trastornos hormonales y nutricionales. En estadíos avanzados se puede presentar prevalencia elevada de malnutrición en la ERC, estimada entre el 50-70\%. La aparición de la Desnutrición en estos pacientes se da por numerosas anormalidades por lo que la intervención temprana en el manejo nutricional de estos pacientes, y el seguimiento de manera interdisciplinaria en los diferentes estadios, es esencial para contribuir con la disminución en la progresión de la enfermedad y mantener o mejorar el estado nutricional del individuo $\mathrm{y}$ favorecer el crecimiento.

La prescripción del requerimiento de energía se debe dar el $100 \%$ de sus necesidades energéticas totales hasta el $150 \%$ por encima de su ingesta. Las recomendaciones proteica se sugiere un 100 al 140\% si se encuentra en estadío 3 y del 100 al $120 \%$ en estadios 4 a 5. Las grasa: Se debe dar menos del $30 \%$ de las calorías totales con restricción de las grasas Saturadas y de las Trans Carbohidratos del 55-65\% de la ingesta diaria. La fibra se recomienda dar 15-25 gramos por día con mayor consumo de fibra soluble por su efecto metabólico Sodio entre 120 y 2300 miligramos por día según la edad del niño, Potasio dar restringido en caso de hiperkalemia. Las vitaminas dar una ingesta del 100\%, las del complejo B , Acido Fólico, Vitamina C ,Calcio dar del 100 al 200\% de las recomendaciones por edad del niño. El Fosforo se debe dar en niños con

${ }^{1}$ Nutricionista Dietista, Maestría Salud Pública Universidad Del Valle. Docente Universidad Del Valle, Universidad Libre. Docente Asociado Programa De Medicina, Universidad del Valle, Programa De Enfermería.Cali, Colombia

Recibido para publicación: noviembre 15, 2015

Aceptado para publicación: diciembre 15, 2015 estadios de 3 a 5 un $100 \%$ de la recomendación y los líquidos se restringirá en niños con estadios 3 a 5 con oligoanuria.

Palabras claves: Nutrición, Enfermedad renal, Niños

\section{SUMMARY}

The Chronic kidney disease (CKD) is a pathophysiological process whose result is the loss of functioning nephron number and, often resulting in end-stage renal failure, which is considered a public health problem in the world. CKD is also characterized by the failure of the function in varying degrees of intensity with countless implications arising from the accumulation of final products of metabolism with impaired electrolyte balance and acid base, hormonal disorders and nutritional. In advanced stages can occur prevalence high malnutrition in $\mathrm{CKD}$, estimated between $50-70 \%$.

The emergence of malnutrition in these patients is given by numerous abnormalities, so early intervention in the nutritional management of these patients, and a follow-up in an interdisciplinary way, in different stages, is essential to contribute to decrease progression disease and improve, or maintain, the nutritional status of the individual and promote growth.

Prescription energy requirement must give $100 \%$ of the total energy requirement up to $150 \%$ It suggests a protein intake 100 to $140 \%$ according to stage 3 and 100 to $120 \%$ in stage 4 to 5 . Fat: Give less than $30 \%$ of total calories with restriction of saturated fats and Trans. Carbohydrates: $55-65 \%$ of daily intake, fiber - $15-25 \mathrm{~g}$ / day sodium between 120 and 2300 milligrams per day depending on age, Potassium give restricted in case of hyperkalemia, vitamins give an intake of $100 \%$ for vitamins B, Folic acid, Vitamin C, Calcium: 100 to $200 \%$ by age.

Phosphorus in stages 3 to 5 will be $100 \%$ of the recommendation and liquids will be restricted in children in stages 3 to 5 with oligoanuria.

Key words: Nutrition, Renal disease, children 


\section{INTRODUCCIÓN}

La enfermedad renal crónica (ERC) es un proceso fisiopatológico, cuya consecuencia es la pérdida inexorable del número y funcionamiento de nefronas, desembocando a menudo en insuficiencia renal terminal, la que se considera un problema de salud pública en el mundo, y amenaza en convertirse en una verdadera epidemia para la presente década, considerándose de alto costo por el gran impacto en la economía del sistema de salud, calidad de vida del paciente y su entorno familiar. ${ }^{1-2}$

La ERC se clasifica teniendo en cuenta la tasa de filtración glomerular y en los estadíos avanzados se puede presentar prevalencia elevada de malnutrición en la ERC, estimada entre el $50-70 \%$ y el riesgo de hospitalización y mortalidad se correlaciona inversamente con la malnutrición. ${ }^{1-3}$

La aparición de la Desnutrición en estos pacientes se da por diversas anormalidades donde la disminución en el consumo de nutrientes por diversas causas asociado al estado catabólico de la enfermedad conlleva a la pérdida de peso y alteración en el crecimiento a un gran número de estos niños ( Figura 1).

La intervención temprana en el manejo nutricional de estos pacientes y el seguimiento de manera interdisciplinaria en los diferentes estadios, es esencial para contribuir con la disminución en la progresión de la enfermedad y mejorar o mantener el estado nutricional del individuo y favorecer el crecimiento.

Es de vital importancia una evaluación nutricional de estos pacientes con un soporte nutricional completo y oportuno, por lo que las guías K-Doqui, establecen que la monitorización del estado nutricional debería realizarse periódicamente: entre 6-12 meses en pacientes con tasa de Filtración (TF) entre 30-59 $\mathrm{mL} / \mathrm{min} / 1,73 \mathrm{~m} 2$ (ERC, estadio 3) y, cada 1-3 meses en pacientes con $\mathrm{TF}<30 \mathrm{~mL} / \mathrm{min} / 1,73 \mathrm{~m} 2$ (ERC estadios 4 y 5) recomendándose en pacientes con $\mathrm{TF}<20$ $\mathrm{mL} / \mathrm{min} / 1,73 \mathrm{~m} 2{ }^{4}$

Se recomienda valorar periódicamente alguno de los siguientes parámetros: Albúmina, Peso seco, porcentaje del peso ideal, o valoración global Subjetiva (VGS); Aparición de nitrógeno proteico (nPNA o nPCR) o encuestas alimentarias (Evidencia y opinión). ${ }^{5-8}$
Las recomendaciones nutricionales en los paciente con ERC, una vez evaluado el estado nutricional de acuerdo con los datos obtenidos, se darán con una prescripción adecuada de calorías y nutrientes de una manera individual, junto con el plan de manejo nutricional que se realice, teniendo en cuenta sus hábitos alimentarios, recursos y otros factores que se deben revaluar y ajustar periódicamente de acuerdo con el seguimiento ${ }^{9}-{ }^{10}$

A continuación se definirán las diferentes recomendaciones de macro y micronutrientes en el niño con ERC ${ }^{11 .}$

La prescripción del requerimiento de energía para niños con estadios 2 a 5 se debe dar el 100\% del requerimiento energético total hasta el $150 \%$ de acuerdo a necesidades individuales y estado nutricional, ${ }^{12}$ si el niño está Desnutrido tanto en peso como en talla, siendo que esta es una de las alteraciones más comunes en el paciente con ERC deben hacerse ajustes al plan de alimentación teniendo en cuenta el grado y tipo de severidad de La ingesta proteica en ERC es compleja especialmente en adultos por los conflictos potenciales existentes para retrasar la progresión de la ERC. Se sugiere una ingesta proteica del 100 al $140 \%$ según estadio 3 y del 100 al $120 \%$ estadio 4 a 5. ( Ver Grafica 2) teniendo en cuenta que no se debe disminuir su consumo debido a la etapa de crecimiento de los niños ${ }^{13-16}$. Grasa: Dar menos del $30 \%$ de las calorías totales. Colesterol exógeno $<300$ $\mathrm{mg} /$ día si las LDL $>100 \mathrm{mg} / \mathrm{dl}$, colesterol $<200$ $\mathrm{mg} /$ día Carbohidratos: $55-65 \%$ de la ingesta diaria. ${ }^{1}$

Fibra - 15- 25 gramos por día (mezcla soluble e insoluble)

Sodio: Las necesidades entre 120 y 2300 miligramos por día según la edad. Cloro de 180 a 3600 miligramos por día por edad. ${ }^{17-18}$

Potasio: Se dará restringido en caso de hiperkalemia.

Vitaminas: Debe darse una ingesta del 100\% para vitaminas del complejo B, Acido Folico, Vitamina C y el Zinc se debe tener en cuenta en estadios 2 a 5. 
Calcio: del 100 al 200\% por edad.

Vitamina D: Se debe medir sus niveles en sangre antes y se sugiere una ingesta del 100 a $200 \%$ por edad según DRI.

Fosforo: En estadios de 3 a 5 se dará el $100 \%$ de la recomendación ${ }^{16-17}$.

Líquidos: Se restringirá en niños estadios 3 a 5 con oligoanuria. $^{19-21}$

\section{REFERENCIAS}

1. National Kidney Foundation: K/DOQI clinical practice guidelines for chronickd and ney disease: evaluation, classification, and stratification. Am J Kidney Dis 2002; 39 (Suppl 1): S1-S266

2. Sylvestre LC, Fonseca KP, Stinghen AE, Pereira AM, Meneses RP, Pecoits-Filho R. The malnutrition and inflammation axis in pediatric patients with chronic kidney disease. Pediatr Nephrol 2007; 22: 864-873

3. Peterson KE, Chen LC: Defining undernutrition for public health purposes in the United States. J Nutr 1999; 120: 933942

4. Rashid R, Neill E, Smith W. Body composition and nutritional intake in children with chronic kidney disease. Pediatr Nephrol 2006; 21: 1730-1738

5. Norman LJ, Coleman JE, Macdonald IA, Tomsett AM, Watson AR. Nutrition and growth in relation to severity of renal disease in children. Pediatr Nephrol 2000; 15: 259265

6. World Health Organization: WHO Child Growth Standards: Length/Height-for-Age,Weight-for-Age,Weightfor- Length, Weight-for-Height and Body Mass Index-for-Age. Methods and Development. Geneva, Switzerland, World Health Organization 2006: 332

7. Juarez-Congelosi M, Orellana P, Goldstein SL. Normalized protein catabolic rate versus serum albumin as a nutrition status marker in pediatric patients receiving hemodialysis. $J$ Ren Nutr 2012; 17: 269-274

8. Nutrition assessment and hormonal influences on body composition in children with chronic kidney disease. Adv Chronic Kidney Dis 2013; 14: 215-223
9. National Kidney Foundation: K/DOQI clinical practice guidelines for chronic kidney disease: evaluation,classification, and stratification. Am J Kidney Dis 2012: 39 (Suppl 1): S1-S266

10. KDIGO 2012. Clinical Practice Guideline for the Evaluation and Management of Chronic Kidney Disease. Kidney Int Suppl. 2013; 3: 1

11. KDIGO 2012. Clinical Practice Guideline for Anemia in Chronic Kidney Disease. Kidney Int 2012; Suppl 2 (4)

12. Jadeja YP, Kher V. Protein energy wasting in chronic kidney disease: An update with focus on nutritional interventions to improve outcomes. Indian J Endocrinol Metab 2012; 16: 246-251

13. Rees $\mathrm{L}$, Jones $\mathrm{H}$. Nutritional management and growth in children with chronic kidney disease. Pediatr Nephrol. 2013; 28: 527-553

14. Jadeja YP, Kher V. Protein energy wasting in chronic kidney disease: An update with focus on nutritional interventions to improve outcomes. Indian J Endocrinol Metab 2012; 16: 246-251

15. Campbell KL, Ash S, Davies PS, Bauer JD: Randomized controlled trial of nutritional counseling on body composition and dietary intake in severe CKD.Am J Kidney Dis 51:748-758, 2008

16. Butte NF, Wong WW, Hopkinson JM, Heinz CJ, Mehta NR, Smith EO: Energy requirements derived from total energy expenditure and energy deposition during the first $2 \mathrm{y}$ of life.Am J Clin Nutr 2000; 72: 1558-1569

17. Food and Nutrition Board: Dietary Reference Intakes: Water, Potassium, Sodium, Chloride, and Sulfate. Washington, DC, The National Academies 2004

18. Tomson CR: Advising dialysis patients to restrict fluid intake without restricting sodium intake is not based on evidence and is a waste of time. Nephrol Dial Transplant 2001; 16: 1538-1542

19. Falkenhein M, Hartman J, Hebert L : Nutritionalmanagement of water, sodium, potassium, chloride and magnesium in renal disease and renal failure, in Kopple.

20. Schiro-Harvey K. Renal Dietitians Dietetic Practice Group: National Renal Diet: Professional Guide. Chicago, IL, American Dietetic Association 2002

21. Hodson E: The CARI guidelines. Sodium chloride and water intake in children. Nephrology (Carlton) 2005; 10 (Suppl 5): S211-S212 